\title{
DÖHLE BODIES IN THE LEUCOCYTES OF PATIENTS WITH BURNS
}

\author{
BY \\ W. WEINER AND ELIZABETH TOPLEY \\ From the Birmingham Regional Blood Transfusion Service and the Medical Research Council Industrial \\ Injuries and Burns Research Unit, Birmingham Accident Hospital
}

(RECEIVED FOR PUBLICATION APRIL 20, 1955)

When working in a hospital for infectious diseases, Döhle (1911, 1912a and b) noticed round, blue-staining bodies in the cytoplasm of neutrophil leucocytes of patients suffering from scarlet fever. As these bodies were occasionally reminiscent of spirochaetes, Döhle first assumed them to be the cause of scarlet fever. This is not surprising if one remembers that only a short time before a spirochaete had been discovered as the cause of syphilis. However, the same bodies, which came to be known as Döhle bodies, were observed also in erysipelas (Kolmer, 1912 ; MacEwen, 1913-14), in diphtheria on about the third day (Kolmer, 1912), in typhus (MacEwen, 1913-14 ; Rehder, 1942), and possibly in tuberculosis (Bachman and Lucke, 1918). In measles Kolmer (1912) found them absent, while MacEwen (1913-14)-considered their presence in 12 out of 35 cases as possibly associated with oral sepsis. Döhle bodies were

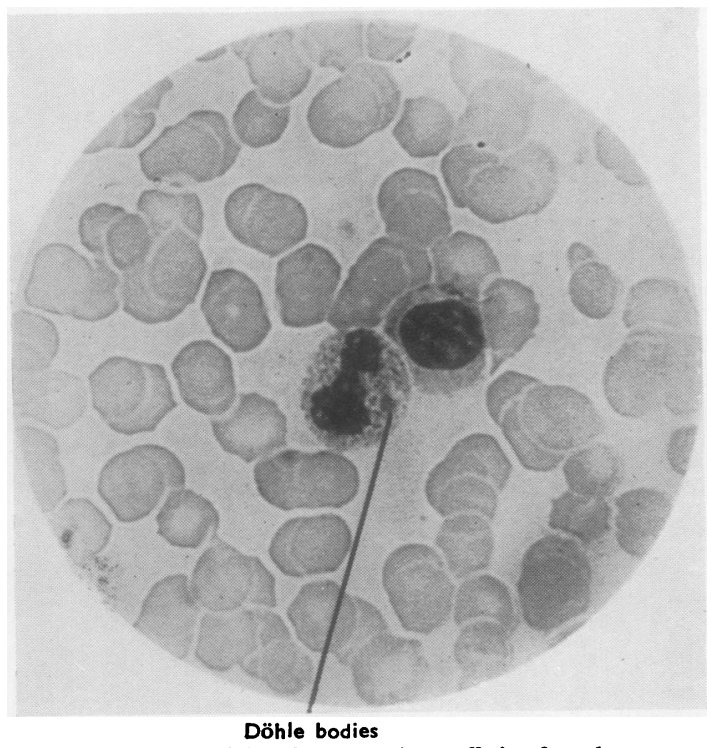

Fig. 1.-A blood film from a patient suffering from burns. described by Kolmer (1912) in a case of scarlet fever complicating burns.

The more modern staining techniques have so far added little to what Döhle clearly described. The bodies (Fig. 1) are usually round or oval shaped and have a diameter from just visible size to approximately 1 to $2 \mu$. They are found most often at the periphery of the cell. With LeishmanGiemsa, or any other of the usual Romanowsky stains, they are a sky blue to grey blue colour and are easily distinguished from the pinkish stained cytoplasm of the neutrophil leucocytes. Some of the cells contain one Döhle body, others may contain up to three or even four. They are always discrete and clearly separated by normal stained cytoplasm. Their staining properties, shape, and position in the cell distinguish them clearly from normal or pathological granulation occurring in neutrophil leucocytes.

The discovery of Döhle bodies in the neutrophil leucocytes of patients with burns was due to a chance observation when a blood film from a patient was examined for a quite different reason. In view of this finding, repeated blood films were taken from patients with burns of different severity in order to ascertain the frequency and timing of their occurrence and any possible association between the presence of Döhle bodies and other features such as the size of the burn, bacterial colonization, anaemia, or leucocytosis.

\section{Material and Methods}

Blood films were taken from 19 consecutive patients admitted to the Burns Unit of the Birmingham Accident Hospital between June 29 and August 15, 1953, and from nine patients with burns involving more than $13 \%$ of the body surface admitted later. Numerous cases have been investigated since then, but are not included in Tables I and II.

Blood films were prepared from capillary blood in the usual way about three times a week for the first three weeks and then weekly. They were stained by 
Leishman-Giemsa. To avoid bias one of us was responsible for the collection of the clinical data and for the making of the films. The films were coded with serial numbers and examined by the other without knowledge of the origin of the film. At the end of the investigations the results were compared. Differential counts of at least 300 white cells were performed on a number of films. All other films were carefully examined for the presence of Döhle bodies. Structures found in the cytoplasm of the cells were counted as Döhle bodies, only if they conformed fully with all the characteristics given in the introduction. No note was made of their single or multiple occurrence in one or the same cell.

\section{Results}

Of the 19 consecutive patients admitted between the dates given above, 11 showed Döhle bodies at some time after their admission. The clinical details of these cases are shown in Table I. Of the 14 burns patients with $2 \%$ or less full-thickness skin loss, only six showed Döhle bodies: all five patients with more than $2 \%$ full-thickness skin loss showed Döhle bodies. Table I also includes nine patients admitted later, all with more than $13 \%$ full-thickness skin loss. All of these showed Döhle bodies. In two patients admitted to this hospital in 1955 the burns involving 10 to $14 \%$ full-thickness skin loss were primarily excised on the day of admission, and the grafts took almost perfectly. No Döhle bodies appeared in the leucocytes of these patients.

Inspection of Table I also suggests that there is a relationship between the incidence of Döhle bodies, pyrexia, bacterial colonization, and mortality. A direct association between the area of the burn and such clinical and pathological findings is already well recognized. This means that in order to seek for a positive association between Döhle bodies and a certain pathological finding, e.g., bacterial colonization, it is necessary to allow for the severity of the burn. The present evidence shows that Döhle bodies are more common in more extensive burns.

Döhle bodies have been found in patients whose burns were not colonized by group A streptococci, coagulase-positive staphylococci, coliform bacilli, or Ps. pyocyanea, and in patients who had not received any blood transfusions, plasma, or dextran. None of these factors alone would therefore appear to be essential by itself for the appearance of Döhle bodies.

Table II and Fig. 2 show the incidence of Döhle bodies at different times after burning. They have rarely been seen on the day of the burn, and the many abnormalities observed during the first hour after a severe burn, though on occasion somewhat

TABLE I

INCIDENCE OF DÖHLE BODIES IN 28 BURNS

\begin{tabular}{|c|c|c|c|c|c|c|c|c|c|c|c|c|}
\hline & \multirow{2}{*}{ Patient } & \multirow{2}{*}{$\begin{array}{c}\text { Total } \\
\text { Blood } \\
\text { Films dur- } \\
\text { ing First } \\
\text { Two Weeks }\end{array}$} & \multirow{2}{*}{$\begin{array}{c}\text { Films with } \\
\text { Döhle } \\
\text { Bodies }\end{array}$} & \multicolumn{2}{|c|}{ Area of Burn* } & \multirow[b]{2}{*}{ Total } & \multirow{2}{*}{$\begin{array}{c}\text { Maximum } \\
\text { Pyrexia } \\
\left({ }^{\circ} \mathrm{F} \text {.) First }\right. \\
2 \text { Weeks }\end{array}$} & \multirow{2}{*}{ Died } & \multicolumn{4}{|c|}{$\begin{array}{l}\text { Bacterial Colonization of Burn } \\
\text { First } 2 \text { Weeks in Hospital }\end{array}$} \\
\hline & & & & $\begin{array}{l}\text { Full- } \\
\text { thickness } \\
\text { Skin } \\
\text { Loss }\end{array}$ & $\begin{array}{l}\text { Partial } \\
\text { Skin } \\
\text { Loss }\end{array}$ & & & & $\begin{array}{l}\text { Group A } \\
\text { H. S. }\end{array}$ & $\begin{array}{c}\text { Coagulase } \\
\text { +ve } \\
\text { Staphy- } \\
\text { lococci }\end{array}$ & $\begin{array}{c}\text { Ps. } \\
\text { Pyocy- } \\
\text { anea }\end{array}$ & $\begin{array}{c}\text { Coliform } \\
\text { Bacilli }\end{array}$ \\
\hline $\begin{array}{l}19 \text { consecutive } \\
\text { cases }\end{array}$ & $\begin{array}{l}\mathbf{A} \\
\mathbf{B} \\
\mathbf{C} \\
\mathbf{D} \\
\mathbf{E} \\
\mathbf{F} \\
\mathbf{G} \\
\mathbf{H} \\
\mathbf{I} \\
\mathbf{J} \\
\mathbf{K} \\
\mathbf{L} \\
\mathbf{M} \\
\mathbf{N} \\
\mathbf{O} \\
\mathbf{P} \\
\mathbf{Q} \\
\mathbf{R} \\
\mathbf{S}\end{array}$ & $\begin{array}{l}2 \\
2 \\
6 \\
6 \\
5 \\
2 \\
1 \\
4 \\
4 \\
3 \\
6 \\
5 \\
5 \\
1 \\
4 \\
5 \\
6 \\
6 \\
5\end{array}$ & $\begin{array}{l}0 \\
0 \\
1 \\
0 \\
0 \\
0 \\
0 \\
4 \\
3 \\
1 \\
0 \\
3 \\
4 \\
0 \\
3 \\
3 \\
2 \\
4 \\
5\end{array}$ & $\begin{array}{c}0 \\
0 \\
0 \\
<\frac{1}{4} \\
\frac{1}{4} \\
0 \cdot 3 \\
\frac{3}{4} \\
\frac{3}{2} \\
\quad 1^{\frac{1}{2}} \\
1 \\
1 \\
1 \\
1 \\
2 \\
4 \\
5 \\
7 \\
12 \\
14\end{array}$ & $\begin{array}{c}5 \\
5 \\
17 \\
0 \\
0 \\
0 \\
61 \\
0 \\
9 \frac{1}{2} \\
13+ \\
4 \\
2 \\
14 \\
4 \frac{1}{2} \\
6 \\
15 \\
13 \\
13 \\
0\end{array}$ & $\begin{array}{c}5 \\
5 \\
17 \\
<\frac{1}{4} \\
\frac{1}{4} \\
0 \cdot 3 \\
7 \\
\frac{1}{2} \\
10^{\frac{1}{2}} \\
14 \\
5 \\
3 \\
15 \\
6 \frac{1}{2} \\
10 \\
20 \\
20 \\
25 \\
14\end{array}$ & $\begin{array}{r}104 \\
99 \\
102 \\
99 \\
99 \\
100 \\
102 \\
100 \\
101 \\
100 \\
102 \\
103 \\
103 \\
104 \\
100 \\
100 \\
103 \\
103 \\
\hdashline 103\end{array}$ & $\begin{array}{l}0 \\
0 \\
0 \\
0 \\
0 \\
0 \\
0 \\
0 \\
0 \\
0 \\
0 \\
0 \\
0 \\
0 \\
0 \\
0 \\
0 \\
0 \\
+\end{array}$ & $\begin{array}{r}+ \\
0 \\
0 \\
0 \\
0 \\
0 \\
+ \\
0 \\
0 \\
0 \\
0 \\
\quad+ \\
+ \\
0 \\
+ \\
0 \\
0 \\
0 \\
0 \\
0\end{array}$ & $\begin{array}{l}+ \\
0 \\
+ \\
0 \\
+ \\
0 \\
0 \\
+ \\
+ \\
+ \\
+ \\
+ \\
+ \\
+ \\
+ \\
+ \\
+ \\
+ \\
0\end{array}$ & $\begin{array}{l}0 \\
0 \\
+ \\
0 \\
0 \\
+ \\
+ \\
0 \\
+ \\
0 \\
0 \\
+ \\
+ \\
0 \\
+ \\
+ \\
+ \\
+ \\
+\end{array}$ & $\begin{array}{l}0 \\
0 \\
+ \\
0 \\
0 \\
+ \\
+ \\
+ \\
+ \\
+ \\
0 \\
+ \\
+ \\
+ \\
+ \\
+ \\
+ \\
+ \\
+\end{array}$ \\
\hline $\begin{array}{l}9 \text { further cases } \\
\text { selected beca use } \\
\text { of large area } \\
\text { of burn }\end{array}$ & $\begin{array}{l}\mathbf{T} \\
\mathbf{U} \\
\mathbf{V} \\
\mathbf{W} \\
\mathbf{X} \\
\mathbf{Y} \\
\mathbf{Z} \\
\mathbf{A Z} \\
\mathbf{B Z}\end{array}$ & $\begin{array}{l}5 \\
8 \\
6 \\
3 \\
2 \\
5 \\
3 \\
3 \\
4\end{array}$ & $\begin{array}{l}4 \\
7 \\
5 \\
2 \\
2 \\
4 \\
3 \\
2 \\
4\end{array}$ & $\begin{array}{c}14 \\
20 \\
20 \\
25 \\
27 \\
40 \\
\text { Not k } \\
\text { Not k } \\
70\end{array}$ & 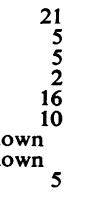 & $\begin{array}{l}35 \\
25 \\
25 \\
27 \\
43 \\
50 \\
60 \\
70 \\
75\end{array}$ & $\begin{array}{l}104 \\
104 \\
106 \\
104 \\
103 \\
102 \\
103 \\
104 \\
101\end{array}$ & $\begin{array}{l}\mathbf{0} \\
\mathbf{0} \\
\mathbf{0} \\
\mathbf{0} \\
\mathbf{0} \\
\mathbf{0} \\
+ \\
+ \\
+\end{array}$ & $\begin{array}{l}0 \\
0 \\
+ \\
0 \\
0 \\
+ \\
0 \\
0 \\
0\end{array}$ & $\begin{array}{l}+ \\
+ \\
+ \\
+ \\
+ \\
+ \\
+ \\
+ \\
+\end{array}$ & $\begin{array}{l}+ \\
+ \\
+ \\
0 \\
+ \\
0 \\
+ \\
0 \\
+\end{array}$ & $\begin{array}{l}+ \\
+ \\
+ \\
+ \\
+ \\
+ \\
+ \\
+ \\
+\end{array}$ \\
\hline
\end{tabular}


TABLE II

INCIDENCE OF Dర̈HLE BODIES AT DIFFERENT PERIODS AFTER THE BURN

\begin{tabular}{|c|c|c|c|c|c|c|c|c|c|c|c|c|}
\hline \multirow{2}{*}{ Patients (see Table I) } & \multirow{2}{*}{$\begin{array}{l}\text { Blood Films } \\
\text { with Döhle } \\
\text { Bodies }\end{array}$} & \multicolumn{7}{|c|}{ Days } & \multicolumn{4}{|c|}{ Weeks } \\
\hline & & 1 & 2 & 3 & 4 & 5 & 6 & 7 & 2 & $3 \& 4$ & $5 \& 6$ & $>6$ \\
\hline 19 consecutive cases & $\begin{array}{c}+ \\
\mathbf{0} \\
\text { Total }\end{array}$ & $\begin{array}{l}0 \\
1 \\
1\end{array}$ & $\begin{array}{r}2 \\
9 \\
11\end{array}$ & $\begin{array}{l}\mathbf{1} \\
\mathbf{1} \\
\mathbf{2}\end{array}$ & $\begin{array}{r}5 \\
5 \\
10\end{array}$ & $\begin{array}{l}2 \\
2 \\
4\end{array}$ & $\begin{array}{l}2 \\
7 \\
9\end{array}$ & $\begin{array}{l}2 \\
0 \\
2\end{array}$ & $\begin{array}{l}14 \\
23 \\
37\end{array}$ & $\begin{array}{r}4 \\
20 \\
24\end{array}$ & $\begin{array}{l}0 \\
9 \\
9\end{array}$ & $\begin{array}{l}0 \\
8 \\
8\end{array}$ \\
\hline $\begin{array}{l}9 \text { further cases selected because } \\
\text { of large area of burn }\end{array}$ & $\begin{array}{c}+ \\
0 \\
\text { Total }\end{array}$ & $\begin{array}{l}2 \\
4 \\
6\end{array}$ & $\begin{array}{l}2 \\
1 \\
3\end{array}$ & $\begin{array}{l}4 \\
0 \\
4\end{array}$ & $\begin{array}{l}6 \\
0 \\
6\end{array}$ & $\begin{array}{l}4 \\
0 \\
4\end{array}$ & $\begin{array}{l}2 \\
0 \\
2\end{array}$ & $\begin{array}{l}3 \\
0 \\
3\end{array}$ & $\begin{array}{r}9 \\
1 \\
10\end{array}$ & $\begin{array}{r}9 \\
2 \\
11\end{array}$ & $\begin{array}{l}3 \\
2 \\
5\end{array}$ & $\begin{array}{r}2 \\
11 \\
13\end{array}$ \\
\hline Total 28 cases . & $\begin{array}{c}\text { Proportion } \\
\text { positive }\end{array}$ & $2 / 7$ & $4 / 14$ & $5 / 6$ & $11 / 16$ & $6: 8$ & $4 / 11$ & $5 / 5$ & $23 / 47$ & $13 / 35$ & $3 / 14$ & $2: 21$ \\
\hline
\end{tabular}

obscuring the picture, were certainly not obscuring the presence of Döhle bodies. Somewhat more frequently than on the day of the burn, they were seen 24 hours afterwards and usually reached their highest incidence by the third day.

Repeated blood films have been taken during the first 12 hours in a very extensive burn $(80 \%$ of the body surface). Döhle bodies were not definitely seen until the twelfth hour, although there was a primary leucocytosis of 47,000 white cells per cubic millimetre by the sixth hour.

In many cases Döhle bodies have disappeared by the third week, but in more extensive burns they may persist for six weeks or more (Fig. 2, Table II). Döhle bodies frequently disappear at about the time of near complete skin cover and clinical convalescence of the patient.

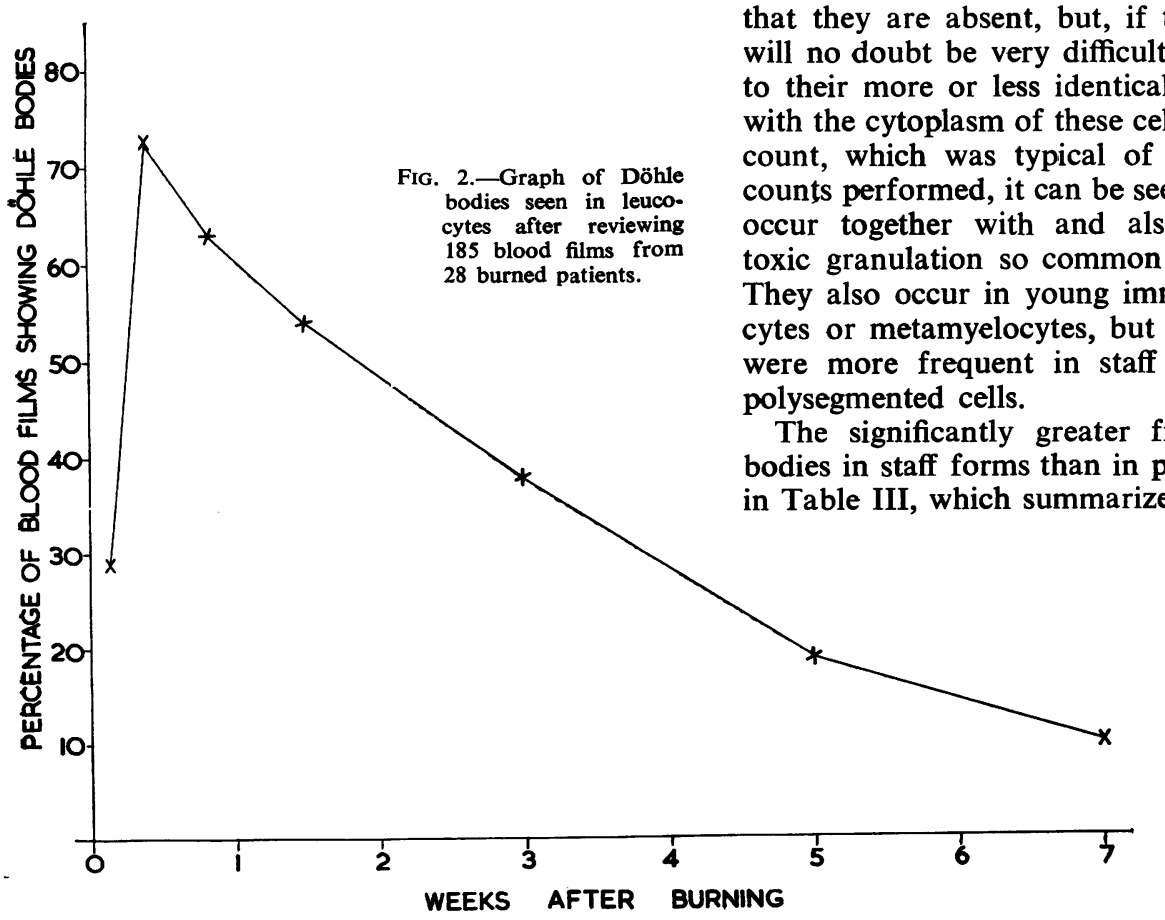

A typical blood count in a fairly severely burned $\stackrel{\omega}{S}$ patient $(25 \%$ of body surface) gave the following values on the third day after injury:

Myelocyte containing Döhle bodies but no toxic granulation Metamyelocyte with no toxic granulation or Döhle bodies " " toxic granulation but no Döhle bodies " " Döhle bodies but no toxic granulation Polymöphs with no toxic granulation or Döhle bodies .

$$
\text { " " toxic granulation but no Döhle bodies }
$$

" " Döhle bodies but no toxic granulatio Staff forms with no toxic granulation or Döhle bodies " " , toxic granulation but no Döhle bodies ", , , Döhle bodies but no toxic granulation Lymphocytes" Eosinophils Basophils

Monocytes
Plasma cells toxic granulation and Döhle bodies

Döhle bodies were not recognized in monocytes or lymphocytes. This does not necessarily mean that they are absent, but, if they do occur, they will no doubt be very difficult to recognize owing $\frac{}{\Phi}$ to their more or less identical staining properties $\stackrel{2}{a}$ with the cytoplasm of these cells. From the above $\overline{0}$ count, which was typical of a number of other 3 counts performed, it can be seen that Döhle bodies occur together with and also independently of toxic granulation so common in burned patients. They also occur in young immature cells (myelo- $:$ cytes or metamyelocytes, but see also below) and 3 were more frequent in staff forms than in the

The significantly greater frequency of Döhle 0 bodies in staff forms than in polymorphs is shown in Table III, which summarizes counts of 15 films from patients with burns.

We did not feel N justified in per-N forming marrow $\sigma$ punctures on these patients, as some of them were too ill and most of them were chil- 0 dren. We had, $\stackrel{\overrightarrow{\mathrm{D}}}{\mathrm{Q}}$ 
TABLE III

DIFFERENTIAL COUNTS (300 CELLS) OF 15 FILMS FROM SEVEN PATIENTS WITH BURNS INVOLVING 5-25\% OF THE BODY AREA SHOWING INCIDENCE OF DÖHLE BODIES IN STAFF FORMS AND POLYMORPHONUCLEAR LEUCOCYTES

\begin{tabular}{|c|c|c|c|c|c|c|c|c|}
\hline Patient & $\begin{array}{l}\text { Days } \\
\text { after } \\
\text { Burn }\end{array}$ & $\begin{array}{c}\text { Polymorpho- } \\
\text { nuclear } \\
\text { Leucocytes }\end{array}$ & $\begin{array}{l}\text { Polymorphs } \\
\text { with Döhle } \\
\text { Bodies }\end{array}$ & $\begin{array}{l}\% \text { of Döhle } \\
\text { Bodies in } \\
\text { Polymorphs }\end{array}$ & $\begin{array}{c}\text { All } \\
\text { "Staff" } \\
\text { Forms }\end{array}$ & $\begin{array}{c}\text { "Staff" Forms } \\
\text { with Döhle } \\
\text { Bodies }\end{array}$ & $\begin{array}{l}\% \text { of Döhle } \\
\text { Bodies in } \\
\text { "Staff" Forms }\end{array}$ & $\begin{array}{c}\text { Higher } \\
\text { Incidence of } \\
\text { Döhle Bodies in }\end{array}$ \\
\hline $\begin{array}{cl}\mathbf{A} \\
\mathbf{O} \\
\mathbf{O} \\
\mathbf{P} \\
\mathbf{P} \\
\mathbf{P} \\
\mathbf{Q} \\
\mathbf{Q} \\
\mathbf{R} \\
\mathbf{R} \\
\mathbf{R} \\
\mathbf{S} \\
\mathbf{S} \\
\mathbf{S} \\
\text { Not in Table I }\end{array}$ & $\begin{array}{r}7 \\
1 \\
3 \\
3 \\
6 \\
8 \\
10 \\
12 \\
3 \\
5 \\
7 \\
1 \\
3 \\
5 \\
35\end{array}$ & $\begin{array}{l}25 \cdot 0 \\
75 \cdot 9 \\
64 \cdot 3 \\
67 \cdot 4 \\
55 \cdot 9 \\
51 \cdot 6 \\
44 \cdot 1 \\
25 \cdot 0 \\
61 \cdot 0 \\
60 \cdot 0 \\
49 \cdot 3 \\
78.7 \\
24 \cdot 7 \\
28.4 \\
22.6\end{array}$ & $\begin{aligned} 10.0 \\
0.3 \\
1.3 \\
11.0 \\
16.6 \\
4.3 \\
2.7 \\
13.0 \\
9.0 \\
30.7 \\
15.3 \\
0.7 \\
10.3 \\
23.7 \\
1.0\end{aligned}$ & $\begin{array}{r}40 \cdot 0 \\
0.4 \\
2 \cdot 0 \\
16 \cdot 4 \\
29 \cdot 7 \\
8 \cdot 3 \\
6 \cdot 1 \\
52 \cdot 0 \\
14 \cdot 8 \\
51 \cdot 1 \\
31 \cdot 0 \\
0.9 \\
41 \cdot 7 \\
83.4 \\
4 \cdot 4\end{array}$ & $\begin{array}{r}9 \cdot 3 \\
7 \cdot 6 \\
5 \cdot 9 \\
16 \cdot 9 \\
24 \cdot 7 \\
20 \cdot 3 \\
14 \cdot 1 \\
28 \cdot 1 \\
18 \cdot 0 \\
15 \cdot 8 \\
32.9 \\
9.6 \\
33 \cdot 5 \\
34 \cdot 7 \\
2 \cdot 0\end{array}$ & $\begin{aligned} 5 \cdot 0 \\
0 \cdot 3 \\
0 \cdot 3 \\
5.6 \\
11 \cdot 0 \\
3 \cdot 0 \\
0 \cdot 7 \\
18.9 \\
7 \cdot 3 \\
8 \cdot 4 \\
14 \cdot 3 \\
0.3 \\
12.9 \\
33 \cdot 1 \\
0 \cdot 3\end{aligned}$ & $\begin{array}{r}53 \cdot 8 \\
4 \cdot 0 \\
5 \cdot 1 \\
33 \cdot 1 \\
44 \cdot 5 \\
14.8 \\
5 \cdot 0 \\
67 \cdot 3 \\
40.6 \\
53 \cdot 1 \\
43 \cdot 5 \\
3 \cdot 1 \\
38.5 \\
95 \cdot 4 \\
15.0\end{array}$ & $\begin{array}{l}\text { Staff forms } \\
\text { ", ", } \\
, ", \\
\text { ", ", } \\
\text { Polymöphs } \\
\text { Staff forms } \\
\text { " ", } \\
\text { ", ", } \\
\text { Pöymorphs } \\
\text { Staff forms } \\
\text {, ", }\end{array}$ \\
\hline
\end{tabular}

The $\chi^{2}$ distribution of Döhle bodies between staff and polymorphonuclear leucocytes shows a highly significant preponderance in the staff forms $(P=<0.001)$

however, occasion to examine marrows from two patients shortly after their death. On examination of the films obtained, one gained the impression that the myeloid series showed a fairly gross disturbance of maturation. Otherwise typical myelocytes showed a blue cytoplasm in spite of the fact that their granulation and nuclei were already fully mature. Some metamyelocytes showed big patches of blue cytoplasm on many occasions. It is conceivable that Döhle bodies as found in the more mature cells are the remains of these patches of blue cytoplasm. However, the films had been taken after death and, as it is well known that very rapid changes occur in the marrow cells after the death of the patient, it would not appear to be safe to base any conclusions on these observations.

\section{Discussion}

The finding of Döhle bodies in burned patients was unexpected. They had been seen previously, as already pointed out, in scarlet fever, other streptococcal infections, diphtheria, typhus, and tuberculosis. Kolmer (1912) has described the occurrence of Döhle bodies in scarlet fever which complicated burns, but he regards their occurrence as due to the scarlet fever and does not discuss any connexion with the burn. Morphologically, the bodies seen in the films taken from burned patients were identical with those obtained in scarlet fever. They were more common in patients with extensive full-thickness skin loss. They appeared during the first few days and persisted for two or more weeks after burning, often until near complete skin cover had been obtained. This timing is very similar to the acute anaemia of burns which is due largely to an unexplained disappearance of red cells ; but scanty numbers of
Döhle bodies have been seen in patients with burns of too small an area for the haemoglobin to fall below 11.8 g. \%. However, still more data are required to establish the significance of the association between Döhle bodies and area of remaining full-thickness skin loss or degree of anaemia.

The appearance of Döhle bodies on the second or third day does not coincide with the height of the total neutrophil leucocyte count in the peripheral blood, but it is possible that it does coincide with the first rapid new formation of leucocytes. Leucocytes disappear into the burned area within the first few hours, but dense polymorphonuclear leucocyte infiltration may take one or two days to form in the burn area (Gordon, Hall, Heggie, and Horne, 1946 ; Moritz, 1947), and massive purulent exudate (present even in burns from which no bacteria were cultivated) is usually not seen on the burned surface until the third day. It is possible, therefore, that the fall in the total polymorphonuclear leucocyte count often seen in the peripheral count on the second or third day (Van Duyn, 1945 ; Sevitt, 1951) is associated with an increased rate of formation of leucocytes and an even more increased rate of loss of leucocytes into the burned area. This is the time of the appearance of Döhle bodies in the leucocytes of the peripheral blood.

A common cause of the occurrence of these marked changes in the cytoplasm of leucocytes has not been found in the diseases in which Döhle bodies have already been reported, although most were associated with a polymorphonuclear leucocytosis. Any "new" morphological change noticed always poses the questions, What is it, what is the cause underlying it, and what is its clinical and pathological significance? None of 
these questions can be answered with the present evidence, but it is hoped that our observation may lead to further investigation into the problem.

It may be that the presence of Döhle bodies reflects one of the many changes in biochemistry of the neutrophil leucocytes taking part in an acute reticulo-endothelial response. In all cases reported so far (with the possible exception of typhus fever) the appearance of Döhle bodies coincided more or less with the appearance of a polymorphonuclear leucocytosis. Histochemical and biochemical investigations on these leucocytes may possibly give results which would clarify the problem of their causation. From the morphological point of view, a very precise knowledge of their incidence in different diseases might increase our knowledge of their pathological significance. For example, it is not known whether they always occur in bacterial infections which produce a leucocytosis or whether they may on occasion also appear in leucopenic pictures. It is not known how often there is an associated unexplained disappearance of red cells. On occasion it has been claimed that leukaemic leucocytes have never shown Döhle bodies, whereas other observers have described Döhle bodies occurring in myelogenous leukaemia. They have, to our knowledge, not been described in pernicious anaemia or haemolytic anaemias and nothing is known of their appearance in the reticuloses. As Döhle bodies are easily overlooked, it may perhaps be rewarding to look out for them regularly in conditions where $\stackrel{0}{\overrightarrow{5}}$ their occurrence has not been described or 을 suspected.

\section{Summary}

Döhle bodies have been found to be frequently $\frac{\bar{\sigma}}{\bar{D}}$. present in the neutrophil leucocytes of patients $\frac{\vec{\sigma}}{\sigma}$ with burns involving more than $2 \%$ of full-thick- $\varrho$ ness skin loss. They appear during the first day $\%$ or two after the burn and often disappear when $\overrightarrow{0}$ complete or nearly complete skin cover is obtained. Their clinical and pathological significance is as $\vec{\omega}$ yet unknown. It is suggested that a more precise knowledge of their incidence in different diseases? might add to our knowledge of their pathological significance.

We wish to thank Dr. E. Lowbury for the use of his bacterial records and Mrs. M. G. Evans and her colleagues for technical assistance; Mr. Gill for the photograph and Miss P. Young for secretarial assistance.

\section{REFERENCES}

Bachman, R. W and Lucke, B. H. (1918), N.Y. med. J., 107, 492. Döhle, P. (1911). Zbl. Bakt., I. Abt. Orig., 61, 63. (1912a). Münch. med. Wschr., 59, 1688 (1912b). Zbl. Bakt., I. Abt. Orig., 65, 57.

Gordon, J., Hall, R. A., Heggie, R. M., and Hcrne, E. A. (1946) 心 J. Path. Bact., 58, 51 .

Kolmer, J. A. (1912). Amer. J. Dis. Child., 4, 1.

MacEwen, W. (1913-14). J. Path. Bact., 18, 456.

Moritz, A. R. (1947). Amer. J. Path., 23, 915.

Mehder, H. (1942). Münch. med. Wschr., 89, 495.

Rehder, H. (1942). Münch. med. Wschr.
Sevitt, S. (1951). Brit. med. J., 1, 976.

Van Duyn, J. (1945). Arch. Surg., Chicago, 50, 242. 